\title{
Effect of seed coat removal and controlled-release fertilizer application on plant emergence and vegetative growth of two citrus rootstocks
}

Eduardo Augusto GIRARDI ${ }^{a}$, Francisco de Assis Alves MOURÃo FILHO ${ }^{a *}$, Ricardo Alfredo KLUGE

\author{
a Departamento de Produção \\ Vegetal, USP/ESALQ, CP 9, \\ Piracicaba, SP, 13418-900, \\ Brazil \\ famourao@esalq.usp.br \\ ${ }^{\mathrm{b}}$ Departamento de Ciências \\ Biológicas, USP/ESALQ, CP 9 , \\ Piracicaba, SP, 13418-900, \\ Brazil
}

Effect of seed coat removal and controlled-release fertilizer application on plant emergence and vegetative growth of two citrus rootstocks.

Abstract - Introduction. The technology for citrus rootstock production through improved sowing methods and fertilizer inputs offers greater opportunity in the certified citrus plant production system. Our work evaluated the influence of seed coat removal and different controlled-release fertilizer concentrations on plant emergence and plant growth of two citrus rootstock cultivars. Materials and methods. Decoated and not decoated seeds of Rangpur lime (Citrus limonia Osbeck) and Swingle citrumelo [Citrus paradisi $\times$ Poncirus trifoliata (L.) Raf] were sown in $50-\mathrm{cm}^{3}$ tubes. Fertilizer concentrations were $(0,1,2,3,4$ and 5$) \mathrm{kg} \cdot \mathrm{m}^{-3}$ of controlled-release fertilizer (NPK 19-06-10) incorporated into the substrate. The experimental layout followed a randomized block design with $2 \times 6$ factorial (seed coat removal $\times$ fertilizer concentration) for each rootstock. Results and discussion. Seed coat removal resulted in faster plant emergence and higher dry weight for both rootstocks. Vegetative growth increased with controlled-release fertilizer concentrations.

Brazil / Citrus / rootstocks / plant propagation / seeds / shelling / fertilizer application / emergence / growth
${ }^{*}$ Correspondence and reprints

Fruits, 2007, vol. 62, p. 13-19 (c) 2007 Cirad/EDP Sciences All rights reserved

DOI: $10.1051 /$ fruits:2006044 www.edpsciences.org/fruits

RESUMEN ESPAÑOL, p. 19
Effet du décorticage de la graine et de l'application d'engrais à libération lente sur la levée et la croissance végétative chez deux porte-greffes d'agrumes.

Résumé - Introduction. Une technique de production de porte-greffes d'agrumes utilisant de meilleures méthodes de semis et d'apports d'engrais pourrait apporter beaucoup aux systèmes de production de plants certifiés d'agrumes. Nos travaux ont évalué l'influence du décorticage de la graine et de différentes concentrations d'engrais à libération lente sur la levée des plantules et la croissance des plants de deux variétés de porte-greffes d'agrumes. Matériel et méthodes. Des graines décortiquées ou non de limes Rangpur (Citrus limonia Osbeck) and de citrumelo Swingle [Citrus paradisi $\times$ Poncirus trifoliata (L.) Raf] ont été semées dans des tubes de $50 \mathrm{~cm}^{3}$. Les concentrations d'engrais à libération lente ont été de $(0,1,2,3,4$ et 5$) \mathrm{kg} \cdot \mathrm{m}^{-3}$ d'engrais (NPK 19-06-10) incorporés au substrat. Le dispositif expérimental adopté a été celui de blocs randomisés à $2 \times 6$ facteur (décortiquage ou non de la graine $\times$ six concentrations d'engrais) pour chacun des deux porte-greffes étudiés. Résultats et discussion. Le décorticage de la graine a entrainé une levée plus rapide et un poids sec de la plantule amélioré pour les deux porte-greffes. La croissance végétative a augmenté avec les concentrations croissantes d'engrais.

Brésil / Citrus / porte greffe / multiplication des plantes / graine / décorticage / fertilisation / levée / croissance 


\section{Introduction}

In citrus, a healthy nursery tree is a key factor leading to the quality and longevity of commercial groves [1]. Thus, the certified production system includes the use of screen houses where grafted seedlings are produced from selected rootstocks grown in adequate substrate, and budwood free of pathogens. This system allows a high control against diseases such as citrus canker, citrus variegated chlorosis and Phytophthora spp. foot rot [2]. Therefore, citrus rootstock production technology, including sowing methods and fertilizer programs, is critical for optimization of the citrus nursery tree production system.

Plant emergence of Rangpur lime and Swingle citrumelo obtained from coated and decoated seeds, 12 to 60 days after sowing $(n=144$, ConchalSP, Brazil, 2001).

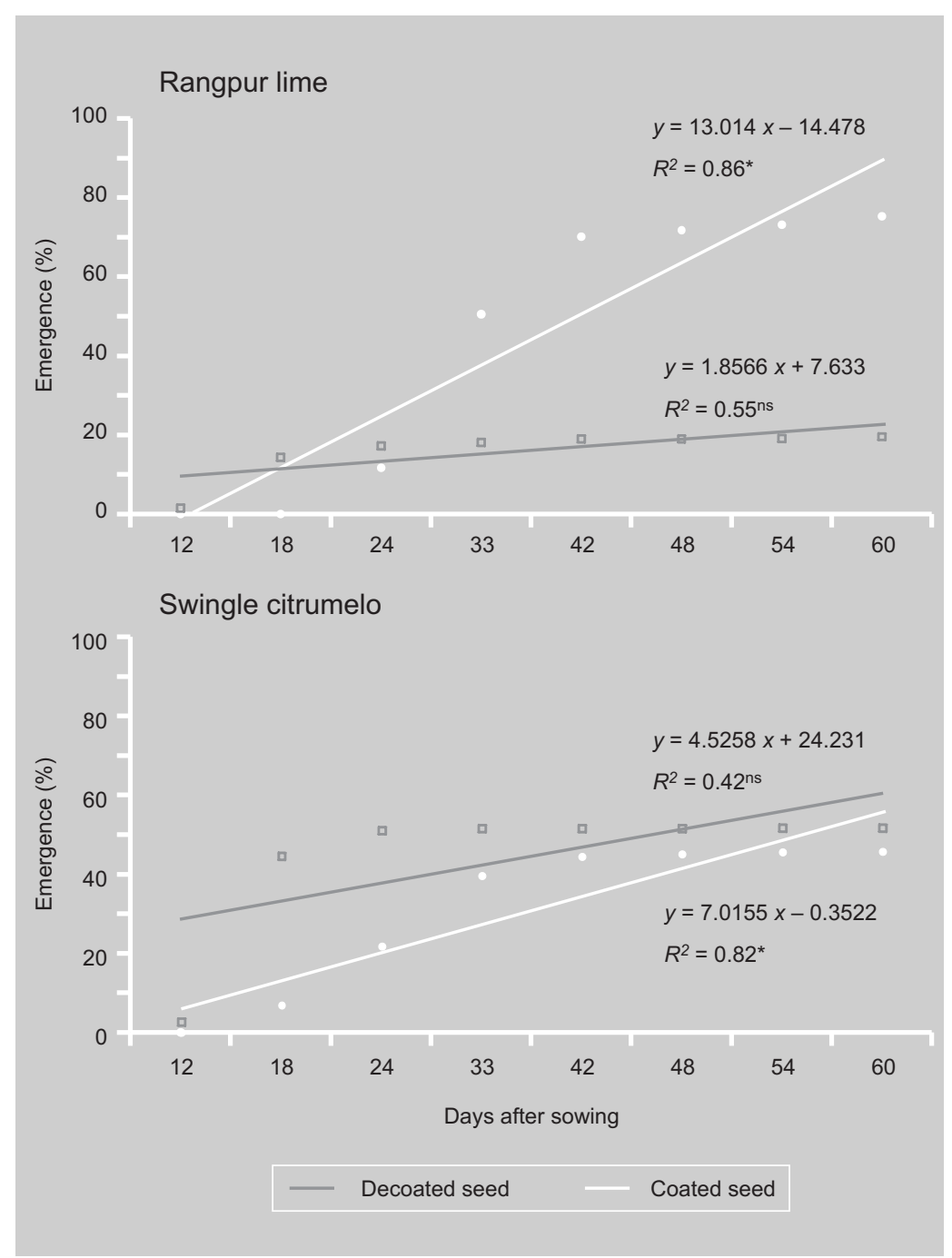

Although external seed coat removal is a labor-intensive activity, this procedure may increase seedling emergence and improve plant quality [3]. Seed coat removal increases the emergence rate of several citrus rootstocks by (30 to 100)\% [4], and it may be manually accomplished after chemical treatment just before sowing. Seedling emergency may vary according to citrus species and cultivar, substrate temperature and salinity levels. Usual germination rates for fresh citrus seeds are higher than 85\% [5]. Temperatures between $(30 \text { and } 35)^{\circ} \mathrm{C}$ lead to maximum seed germination, although it may occur at temperatures as low as $15^{\circ} \mathrm{C}[5,6]$.

On the other hand, alternative fertilizer programs, such as the use of controlled-and slow-release fertilizers [7], may be applied in the citrus nursery tree production system. This group of fertilizers has already been used in some commercial citrus nurseries in Brazil, with similar results compared with conventional soluble fertilizers [8]. Controlled-release fertilizers reduce the number of applications since they can be incorporated into the substrate before planting and lead to a reduction in the production cost. An efficient release of nutrients by fertilizer granules is also observed, as long as moisture is not limited and the substrate temperature is around $21^{\circ} \mathrm{C}$. Gradual nutrient release occurs regardless of substrate permeability, $\mathrm{pH}$ or microbiological activity and it can last from (2 to 15) months depending on the chemical composition and temperature [7]. Our work evaluated the effect of seed coat removal and controlled-release fertilizer concentrations on plant emergence and vegetative growth of two citrus rootstocks.

\section{Materials and methods}

The experiment was carried out from February to May 2001 in a certified citrus commercial nursery located in Conchal, São Paulo State, Brazil $\left(22^{\circ} 38^{\prime} \mathrm{S}, 47^{\circ} 35^{\prime} \mathrm{W}\right.$, $590 \mathrm{~m}$ above sea level). The experiment was carried out inside a screen house with average daily maximum and minimum temperatures of (40.5 and 18.6) ${ }^{\circ} \mathrm{C}$, respectively.

Seeds of Rangpur lime (Citrus limonia, L. Osbeck) and Swingle citrumelo [Citrus 
Table I.

Germination velocity index of Rangpur lime and Swingle citrumelo obtained from coated and decoated seeds, due to controlled-release fertilizer concentration in the substrate, 60 days after sowing ( $n=144$, Conchal-SP, Brazil, 2001).

Controlled-release fertilizer
concentration
$\left(\mathrm{kg} \cdot \mathrm{m}^{-3}\right)$

\begin{tabular}{|c|c|c|c|c|}
\hline \multirow{3}{*}{$\begin{array}{l}\text { Controlled-release fertilizer } \\
\text { concentration } \\
\left(\mathrm{kg} \cdot \mathrm{m}^{-3}\right)\end{array}$} & \multicolumn{4}{|c|}{ 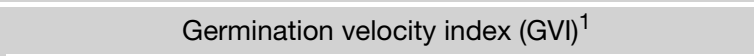 } \\
\hline & \multicolumn{2}{|c|}{ Rangpur lime } & \multicolumn{2}{|c|}{ Swingle citrumelo } \\
\hline & Coated seed & Decoated seed & Coated seed & Decoated seed \\
\hline 0 & $3.63 \mathrm{a}$ & $2.29 \mathrm{~b}$ & $2.46 \mathrm{~b}$ & $4.67 \mathrm{a}$ \\
\hline 1 & $3.67 \mathrm{a}$ & $1.64 \mathrm{~b}$ & $3.10 \mathrm{~b}$ & $5.33 a$ \\
\hline 3 & $3.12 \mathrm{a}$ & $1.59 \mathrm{~b}$ & $2.82 \mathrm{~b}$ & $5.01 \mathrm{a}$ \\
\hline 3 & $3.46 \mathrm{a}$ & $1.86 \mathrm{~b}$ & $3.03 \mathrm{~b}$ & $5.06 \mathrm{a}$ \\
\hline 4 & $3.39 \mathrm{a}$ & $2.03 \mathrm{~b}$ & $3.22 b$ & $4.80 \mathrm{a}$ \\
\hline 5 & $3.56 \mathrm{a}$ & $1.23 \mathrm{~b}$ & $2.57 \mathrm{~b}$ & $5.43 a$ \\
\hline
\end{tabular}

${ }^{1} \mathrm{GVI}=\mathrm{G}_{1} / \mathrm{N}_{1}+\mathrm{G}_{2} / \mathrm{N}_{2}+\ldots+\mathrm{G}_{\mathrm{n}} / \mathrm{N}_{\mathrm{n}}$, where $\mathrm{G}_{1}, \mathrm{G}_{2}$ and $\mathrm{G}_{\mathrm{n}}$ are the number of germinated seedlings at first, second, and up to the last counting; $N_{1}, N_{2}$ and $N_{n}$ are the number of days from sowing to the first, second, and up to the last counting. For each rootstock, means followed by the same letter in lines do not differ by Tukey's Test $(\alpha=0.05)$.
Figure 2.

Plant emergence of Rangpur lime and Swingle citrumelo obtained from coated and decoated seeds, due to controlled-release fertilizer concentration in the substrate 60 days after sowing $(n=144$, Conchal-SP, Brazil, 2001). paradisi Macfad. $\times$ Poncirus trifoliata (L.) Raf.] rootstocks were stored in a regular refrigerator at $5{ }^{\circ} \mathrm{C}$ for 7 months after harvest.

Seeds were manually decoated when seed coat bruising occurred after seed immersion in a chemical solution ( $2 \mathrm{~L}$ water, $5 \mathrm{~g}$ sodium hydroxide, $0.5 \mathrm{~L}$ sodium hypochlorite and $3 \mathrm{~mL}$ muriatic acid) for $45 \mathrm{~min}$. The controlled-release fertilizer Osmocote $^{\mathrm{TM}}$ with $19 \% \mathrm{~N}, 6 \% \mathrm{P}_{2} \mathrm{O}_{5}$, and $10 \% \mathrm{~K}_{2} \mathrm{O}$ (without any other nutrients) was used at $(0,1,2,3$, 4 and 5) $\mathrm{kg} \cdot \mathrm{m}^{-3}$ of substrate. For this specific formulation, the total nutrient release period lasts (3 to 4) months at a substrate temperature of $21{ }^{\circ} \mathrm{C}$. This fertilizer does not contain any chemical substance reported to improve seed germination. Before sowing, the fertilizer was mechanically incorporated into the substrate by the use of a mixer.

After immersion, seeds were washed in water to eliminate chemical solution residue and were then sown in $50-\mathrm{cm}^{3}$ tubes filled with pine bark substrate. One seed was used per tube. Rangpur lime and Swingle citrumelo were sown at $1.5-\mathrm{cm}$ and $2.5-\mathrm{cm}$ depth, respectively. Just after sowing, seeds were covered with a $1-\mathrm{cm}$ vermiculite layer. An integrated pest management program recommended for a citrus nursery was followed. Irrigation was manual and its level varied with weather conditions and

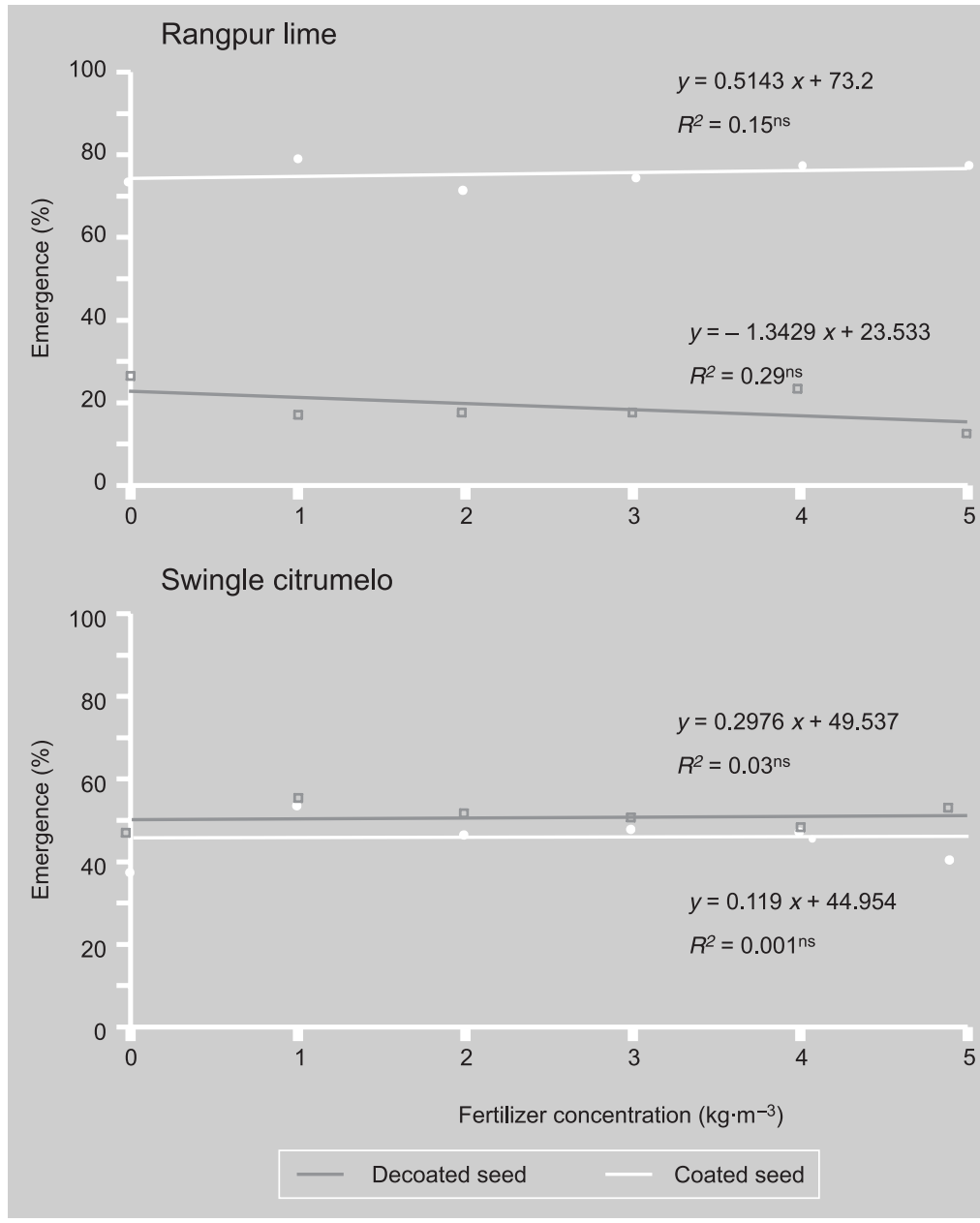



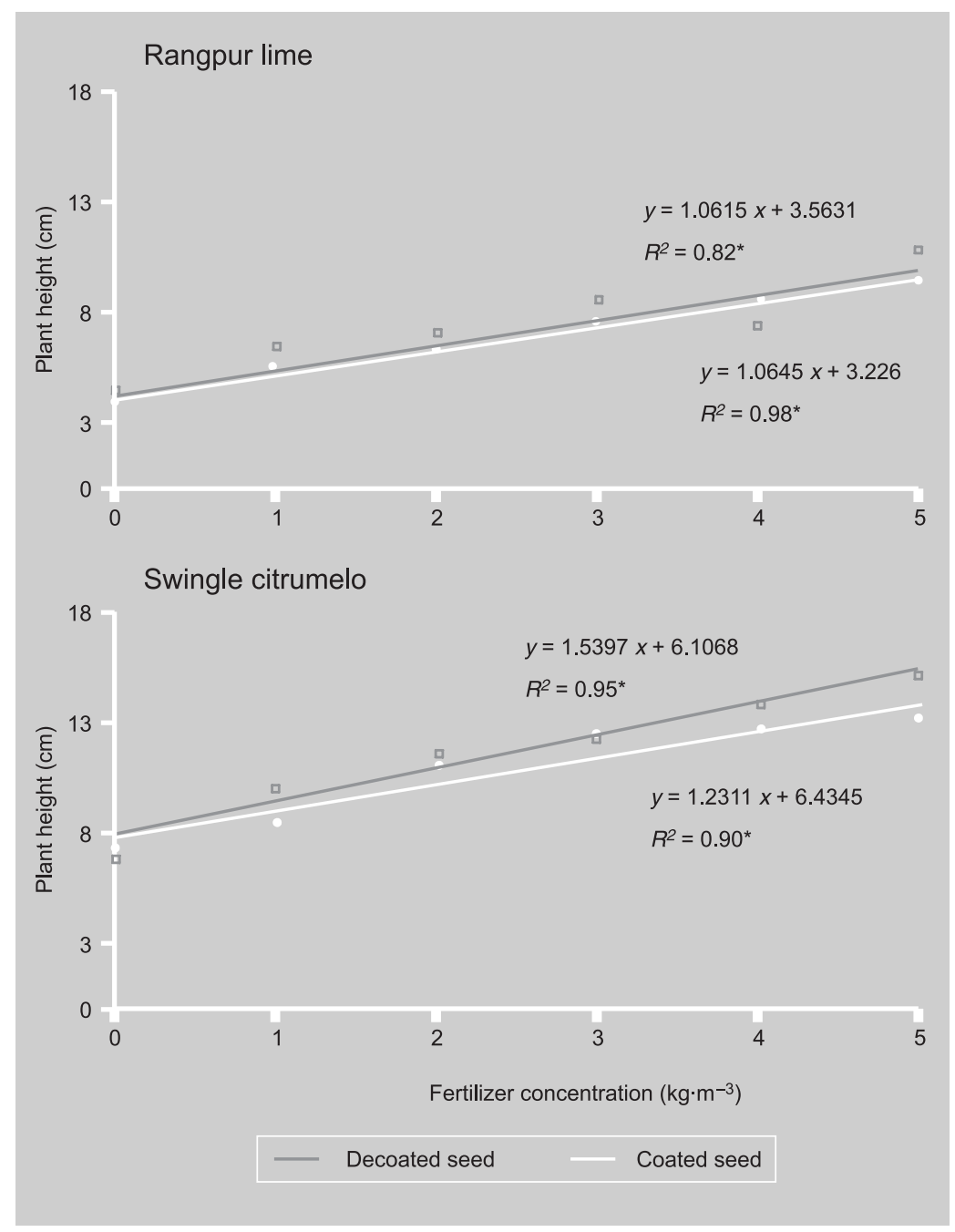

Figure 3.

Plant height of Rangpur lime and Swingle citrumelo obtained from coated and decoated seeds, due to controlled-release fertilizer concentration in the substrate 90 days after sowing $(n=144$, Conchal-SP, Brazil, 2001). substrate saturation [average of (3 to 4) $\mathrm{mm}$ per day].

The experimental layout followed a randomized block design with $2 \times 6$ factorial (seed coat removal $\times$ fertilizer concentration), for each rootstock, with three replications. A 192-cell seed tray was used as a plot and data was collected in the 48 central plants.

The germination velocity index was evaluated 60 days after sowing, with counting being realized at 6-day intervals and the first counting done 12 days after sowing. A germinated seedling was characterized as a minimum 1-cm-high nucellar seedling. Calculation followed the formula recommended by Nakagawa (1994) [9]: GVI $=\mathrm{G}_{1} / \mathrm{N}_{1}+\mathrm{G}_{2} /$
$\mathrm{N}_{2}+\ldots+\mathrm{G}_{\mathrm{n}} / \mathrm{N}_{\mathrm{n}}$, where GVI is the germination velocity index; $G_{1}, G_{2}$ and $G_{n}$ are the number of germinated seedlings at the first, second, and up to the last counting; $\mathrm{N}_{1}, \mathrm{~N}_{2}$ and $\mathrm{N}_{\mathrm{n}}$ are the number of days from sowing to the first, second, and up to the last counting.

The final plant emergence percentage was measured 60 days after sowing. Plant height and scion and root dry weight were collected 90 days after sowing. Dry weight was determined by oven-drying the plant parts at $64{ }^{\circ} \mathrm{C}$ for $48 \mathrm{~h}$. GVI data was subjected to variance analysis through ESTAT statistical software, and means were compared by the Tukey test $(\alpha=0.05)$. The effect of fertilizer concentration on final plant emergence, plant height, and scion and root dry weight was evaluated by linear regression analysis $(P \leq 0.05)$.

\section{Results and discussion}

Decoated seeds started germination about one week earlier than coated seeds for both rootstocks, regardless of the controlledrelease fertilizer concentration (figure 1). This result was probably caused by the removal of inhibitory agents present in the seed coat such as abscisic acid, coumarins and other compounds. Those substances are commonly found in the most external layer of the seed coat of species with fleshy or succulent fruits such as citrus [10, 11].

Higher GVI values indicate faster seed germination [9]. Decoated seeds of Swingle citrumelo led to higher GVI values than coated seeds, but the opposite occurred with Rangpur lime seeds (table I). The low GVI values for Rangpur lime decoated seeds are a result of the substantially lower total plant emergence for Rangpur lime decoated seeds (figure 2), even though germination had started 12 days before Rangpur lime coated seed germination (figure 1).

The presence of the seed coat in citrus also works as a mechanical barrier to root development during germination because of the reduction in oxygen and carbon dioxide diffusion and seed imbibition. There is a correlation between seed coat thickness 
and germination rate. The thicker the seed coat, the greater the relative increase in plant emergence after seed coat removal. Seed coat external texture also influences plant germination. Therefore, smooth seed coats usually correspond to fast-germinating species. Other species have very intensive mucilage deposition on their rough seed coat which is very hard to eliminate even after several washes. The hydrophobic characteristics of seed coat mucilage may explain some of its negative effects on citrus plant germination [4]

Germination evaluation of intergeneric hybrids between Citrus and Poncirus indicated that coated seeds led to a longer germination period and seed coat removal did not influence germination rate [6]. However, in our work, 60 days after sowing, plant emergence was higher for Rangpur lime coated seeds (75\%) than for Rangpur lime decoated seeds (15\%) (figure 2). There was no difference regarding plant emergence for coated and decoated Swingle citrumelo seeds (average of 45\%) (figure 2). Poncirus trifoliata and its hybrids are characterized by a thin and extremely smooth seed coat, and they have similar plant emergence regardless of the presence or absence of the seed coat [4].

The low plant emergence rates observed in this evaluation may result from the relatively long seed storage period, around 7 months after harvest. Rangpur lime coated seeds led to a higher plant emergence percentage than Swingle citrumelo seeds. On the other hand, Rangpur lime decoated seeds had the lowest plant emergence percentage. This could be a result of Rangpur lime seed sensitiveness to the chemical solution used for seed coat removal, or this decrease in emergence could be due to long storage, even though seeds of Poncirus trifoliata and its hybrids are recognized as particularly sensitive to drying and cold conservation [5]. Further investigations involving fresh seeds should be carried out.

Seed coat removal did not influence plant height until 90 days after sowing. However, it led to higher scion and root dry weight with controlled-release fertilizer concentrations higher than $1 \mathrm{~kg} \cdot \mathrm{m}^{-3}$ (figures $3-5$ ). This may be a result of the faster plant emer-
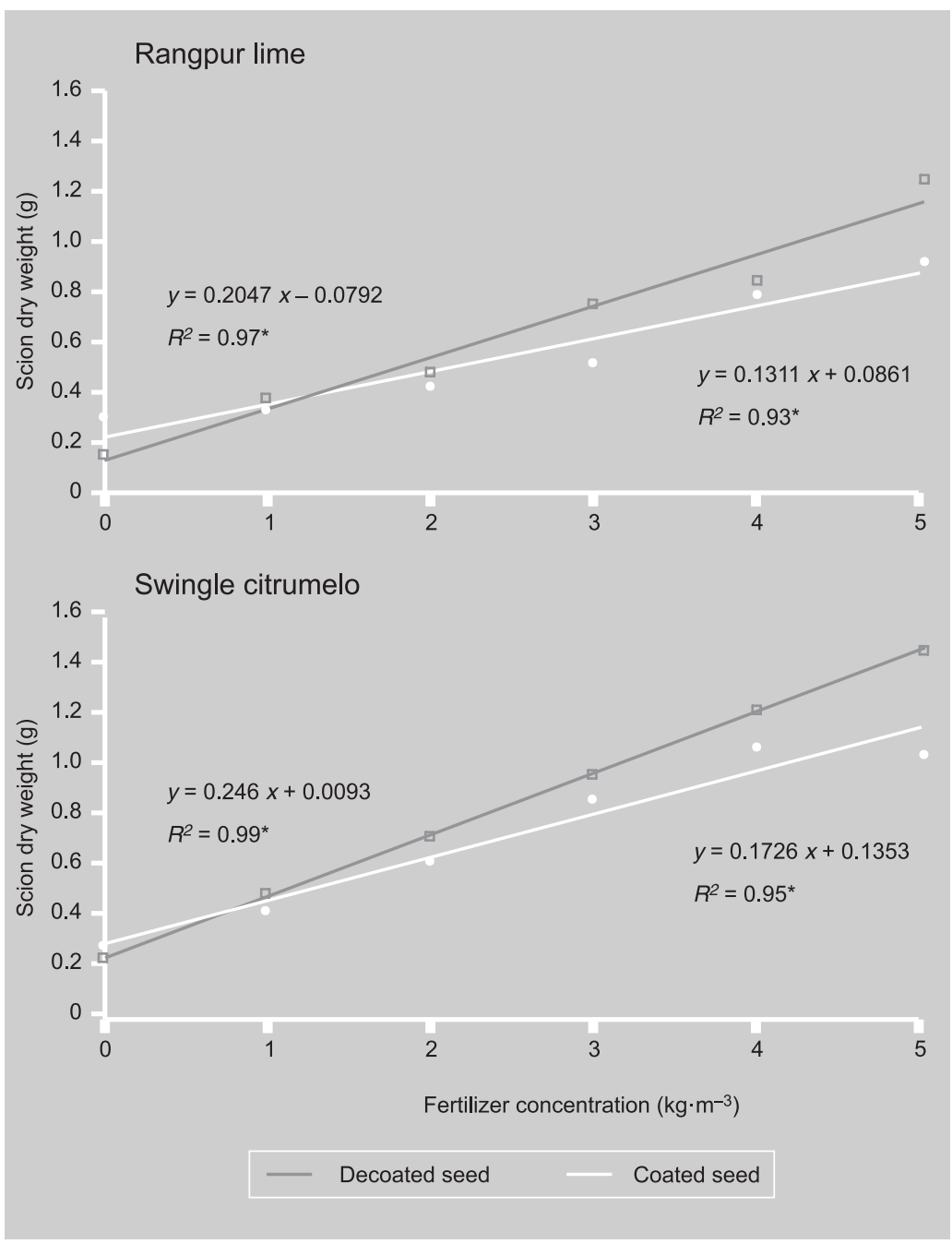

Figure 4.

gence of decoated seeds, resulting in earlier nutrient uptake and dry weight accumulation by seedlings where there was higher nutrient availability. As seed coat removal did not influence plant height until 90 days after sowing, the reason for dry weight differences could also be attributed to some other factors such as fertilizer concentration, water imbibition or temperature. There was no effect of controlled-release fertilizer concentrations on plant emergence (figure 1). Citrus rootstock germination has been affected by high osmotic or salinity levels in the substrate [12, 13]. In the present case, the salinity index of the fertilizer is probably not high enough to decrease germination at the concentrations tested.
Scion dry weight of Rangpur lime and Swingle citrumelo obtained from coated and decoated seeds, due to controlled-release fertilizer concentration in the substrate 90 days after sowing $(n=144$, Conchal-SP, Brazil, 2001). 

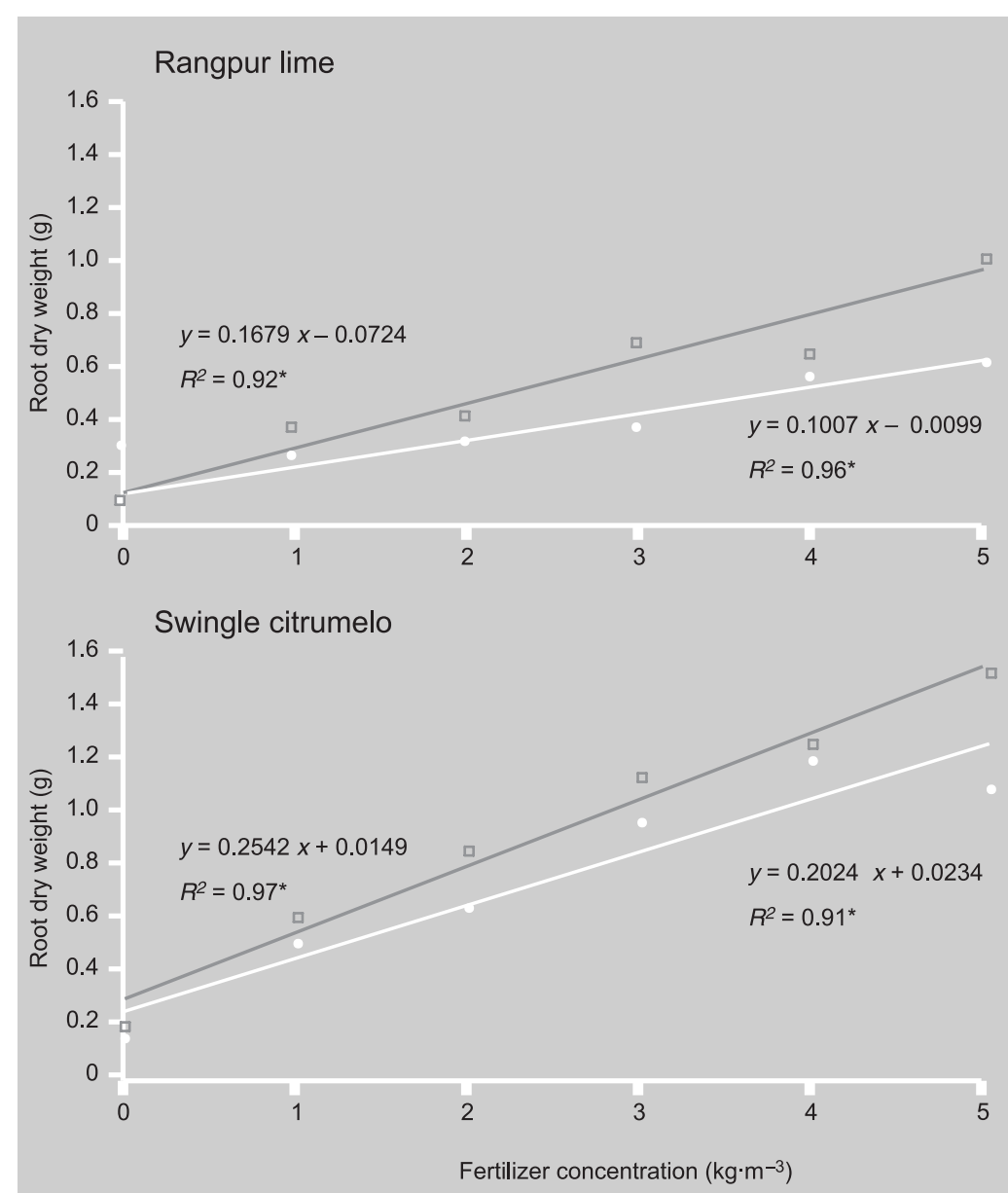

Decoated seed Coated seed

Figure 5.

Root dry weight of Rangpur lime and Swingle citrumelo obtained from coated and decoated seeds, due to controlled-release fertilizer concentration in the substrate 90 days after sowing $(n=144$, Conchal-SP, Brazil, 2001). concentrations greater than $3.5 \mathrm{~kg} \cdot \mathrm{m}^{-3}$ are indicated for adequate vegetative growth of containerized citrus nursery trees [8].

\section{Conclusions}

Seed coat removal allowed plant emergence about one week earlier than coated seeds, leading to $25 \%$ higher scion and root dry weight for both rootstocks.

Plant height increased by up to $125 \%$ with the increase in the fertilizer concentration.

Plant dry weight increased by up to 500\% with the increase in the fertilizer concentration.

\section{Acknowledgements}

The authors thank Citrograf Nursery for the technical support for this experiment.

\section{References}

[1] Teófilo Sobrinho J., Propagação de citros, in: Rodriguez O., Viégas F., Pompeu J. Jr., Amaro A.A. (Eds.), Citricultura Brasileira, Fund. Cargill, Campinas, Brasil, 1991.

[2] Panzani C.R., Prates H.S., Greve A., Sistema de produção de muda certificada de citros no Estado de São Paulo, Laranja 15 (1994) 175-199.

[3] Sempionato O.R., Girotto L.F., Stuchi E.S., Produção de mudas sadias, in: Donadio L.C., Moreira C.S. (Eds.), Clorose variegada dos citros, Fundecitrus, Bebedouro, Brasil, 1997.

[4] Radhamani J., Malik S.K., Chandel K.P.S., Seed coat characteristics in relation to the physiology of seed germination in Citrus and its allied genus, Seed Sci. Technol. 19 (1991) 611-621.

[5] Doijode S.D., Tropical and subtropical fruits - citrus fruits (Citrus spp.), in: Doijode S.D. (Ed.), Seed storage of horticultural crops, Haworth Press Inc., New York, USA, 2001.

[6] Soares Filho W. dos S., Medrado A.C. de M., Cunha Sobrinho M.A.P. da, Passos O.S., 
Freqüência de híbridos em cruzamentos controlados de citros: cultivo de sementes versus cultivo in vitro de embriões, Pesqui. Agropecu. Bras. 37 (2002) 981-988.

[7] Shaviv A., Advances in controlled-release fertilizers, Adv. Agron. 71 (2001) 1-49.

[8] Girardi E.A., Mourão Filho F.A.A., Graf C.C.D., Olic F.B., Influence of soluble and slow release fertilizers on vegetative growth of containerized citrus nursery trees, J. Plant Nutr. 28 (2005) 1465-1480.

[9] Nakagawa J., Testes de vigor baseados na avaliação das plântulas, in: Vieira R.D., Carvalho N.M. (Eds.), Testes de vigor em sementes, Funep, Jaboticabal, Brasil, 1994.

[10] Ketring D.L., Germination inhibitor, Seed Sci. Technol. 1 (1973) 305-324.

[11] Popinigis F., Fisiologia de sementes, Agiplan, Brasília, Brasil, 1977.

[12] Zekri M., Osmotic and toxic ion effects on seedling emergence and nutrition of citrus rootstocks, J. Plant Nutr. 16 (1993) 20132028.
[13] Singh A., Saini M.L., Behl R.K., Seed germination and seedling growth of citrus (Citrus species) rootstocks under different salinity regimes, Indian J. Agric. Sci. 74 (2004) 246248.

[14] Perin J.R., Carvalho S.A., Mattos Junior D., Cantarella H., Efeitos de substratos e doses de fertilizante de liberação lenta no teor de clorofila e desenvolvimento vegetativo do limoeiro Cravo em tubetes, Laranja 20 (1999) 457-462.

[15] Scivittaro W.B., Oliveira R.P., Radmann E.B., Doses de fertilizantes de liberação lenta na formação do porta-enxerto 'Trifoliata', Rev. Bras. Frutic. 26 (2004) 520-523.

[16] Pompeu J. Jr., Porta-enxertos, in: Mattos D. Jr., Negri J.D., Pio R.M., Pompeu J. Jr. (Eds.), Citros, Inst. Agron. Fund., Campinas, Brasil, 2005.

[17] Boaventura P.S., Quaggio J.A., Abreu M.F., Bataglia O.C., Balanço de nutrientes na produção de mudas cítricas cultivadas em susbtrato, Rev. Bras. Frutic. (2004) 300-305.

Efecto del pelado de semillas y de la aplicación de fertilizante de liberación controlada sobre la emergencia y el crecimiento vegetativo de dos porta injertos de cítricos.

Resumen - Introducción. El desarrollo de tecnologías para la producción de porta injertos de cítricos, que incluye métodos de siembra y programas de fertilización, es importante para optimizar el sistema de producción de plantas certificadas en vivero. Este trabajo evaluó el efecto de la remoción de la cubierta seminal y la aplicación de distintas concentraciones de fertilizante de liberación controlada sobre la emergencia y el crecimiento de dos porta injertos. Material y métodos. Semillas peladas o no de lima Rangpur (Citrus limonia Osbeck) y de citrumelo Swingle (Citrus paradisi $\times$ Poncirus trifoliata) fueron sembradas en tubos de $50 \mathrm{~cm}^{3}$. Las concentraciones de fertilizante fueron: $(0 ; 1 ; 2 ; 3 ; 4$ y 5$) \mathrm{kg} \cdot \mathrm{m}^{-3}$ de una formulación de fertilizante (NPK 19-06-10) de liberación controlada, mezclado con el sustrato. El diseño experimental fue de bloques aleatorios, con un arreglo factorial $2 \times 6$ (remoción de la cubierta seminal $\times$ concentración de fertilizante) para cada porta injerto. Resultados y discusión. La remoción de la cubierta seminal aceleró la emergencia de las plantas y produjo un mayor crecimiento vegetativo en ambos porta injertos. El crecimiento vegetativo de los porta injertos aumentó con la aplicación de fertilizante de liberación controlada.

Brasil / Citrus / portainjertos / propagación de plantas / semilla / descascarado / aplicación de abonos / emergencia / crecimiento 